\title{
Endogenous interleukin-10 constrains Th17 cells in patients with inflammatory bowel disease
}

\author{
Cailin M Wilke ${ }^{1,2}$, Lin Wang ${ }^{1}$, Shuang Wei ${ }^{1}$, Ilona Kryczek${ }^{1}$, Emina Huang ${ }^{1}$, John Kao ${ }^{3}$, Yanwei Lin ${ }^{1,4}$, \\ Jingyuan Fang ${ }^{4^{*}}$ and Weiping Zou ${ }^{1,2,5,6^{*}}$
}

\begin{abstract}
Background: Th17 cells play a role in inflammation. Interleukin (IL)-10 is a potent anti-inflammatory cytokine. However, it is poorly understood whether and how endogenous IL-10 impacts the development of Th17 cells in human pathologies.

Materials and methods: We examined the relationship between IL-10 and Th17 cells in patients with Crohn's disease and in IL-10-deficient (IL-10 ${ }^{-1}$ ) mice. Th17 cells and dendritic cells (DCS) were defined by flow cytometry and evaluated by functional studies.

Results: We detected elevated levels of IL-17 and Th17 cells in the intestinal mucosa of patients with Crohn's disease. Intestinal DCs from Crohn's patients produced more IL-1 $1 \beta$ than controls and were superior to blood DCs in Th17 induction through an IL-1-dependent mechanism. Furthermore, IL-17 levels were negatively associated with those of IL-10 and were positively associated those of IL-1 $\beta$ in intestinal mucosa. These data point toward an in vivo cellular and molecular link among endogenous IL-10, IL-1, and Th17 cells in patients with Crohn's disease. We further investigated this relationship in IL-10 $10^{--}$mice. We observed a systemic increase in Th17 cells in $\mathrm{IL}-10^{-/-}$mice when compared to wild-type mice. Similar to the intestinal DCs in patients with Crohn's disease, murine IL-10/DCs produced more IL-1 $\beta$ than their wild-type counterparts and promoted Th17 cell development in an IL-1dependent manner. Finally, in vivo blockade of IL-1 receptor signaling reduced Th17 cell accumulation and inflammation in a mouse model of chemically-induced colitis.
\end{abstract}

Conclusions: Endogenous IL-10 constrains Th17 cell development through the control of IL-1 production by DCs, and reaffirms the crucial anti-inflammatory role of IL-10 in patients with chronic inflammation.

Keywords: Th17, IL-10, IL-1, IL-17, inflammation, Crohn's disease

\section{Introduction}

Inflammation is associated with autoimmune diseases and cancer development [1,2]. Recent studies have emphasized the relevance of Th17 cell function in human diseases, including multiple sclerosis [3], colitis $[4,5]$, psoriasis $[6,7]$ and cancer $[8,9]$. It has been reported that a variety of cytokine cocktails including transforming growth factor beta (TGF $\beta$ ) and the interleukins (IL)-6, IL-1, and IL-23 promote Th17 cell development [10-15], whereas IL-2 inhibits Th17 cell development [16]. It is

\footnotetext{
* Correspondence: jingyuan@yahoo.com; wzou@med.umich.edu 'Department of Surgery, University of Michigan, Ann Arbor, MI, USA ${ }^{4}$ Department of Medicine, Renji Hospital, Shanghai Jiao-Tong University, Shanghai, P. R. China

Full list of author information is available at the end of the article
}

generally accepted that these cytokines directly target $\mathrm{T}$ cells, where they regulate the expression of certain transcription factors and cytokine receptors, and affect Th17 cell development [17-19]. Importantly, however, effector $\mathrm{T}$ helper (Th) cells are polarized by antigen-presenting cells (APCs). The role of APC subsets including dendritic cells (DCs) and macrophages has not been studied in the development of Th17 cells in the microenvironment of intestinal mucosa in patients with Crohn's disease (CD). In this study, we examined the effects of Crohn's APCs and the associated cytokines on Th17 cell induction in patients with CD. We extended and confirmed our human studies in mouse model with chemically-induced intestinal inflammation.

\section{() Biomed Central}

(C) 2011 Wilke et al; licensee BioMed Central Ltd. This is an Open Access article distributed under the terms of the Creative Commons Attribution License (http://creativecommons.org/licenses/by/2.0), which permits unrestricted use, distribution, and reproduction in any medium, provided the original work is properly cited. 
Furthermore, we extended and confirmed our human studies in IL-10-deficient mouse model. IL-10-deficient mice show enhanced development of several inflammatory and autoimmune diseases [20], which partially micmics patients with CD. It suggests that IL-10 may serve a central function in vivo in restricting inflammatory responses in patients with $\mathrm{CD}$. In support of this possibility, it was recently reported that a CD-associated NOD2 mutation suppresses transcription of human IL10 by inhibiting activity of the nuclear ribonucleoprotein hnRNP-A1, and low IL-10 expression is associated with this mutation [21]. IL-10 is an immunosuppressive cytokine that is produced by several cell types, including myeloid APCs [22-25]. IL-10 often directly targets APCs in an autocrine manner and impedes $\mathrm{T}$ cell activation and polarization, thereby reducing inflammation [22,23,26-29]. Thus, it is possible that IL-10 affects the functionality of APCs, impacts Th17 cell development, and Th17-associated human pathogeneses. Thus, we assessed the role of APC-derived IL-10 in both patients with $\mathrm{CD}$ and $\mathrm{IL}-10^{-/-}$mouse model, and investigated the cellular and molecular relationship between IL-10 and Th17 cells in these two systems. Notably, there is strong genetic evidence that IL-23 plays a role in CD. IL-23 receptor polymorphisms were strongly associated with susceptibility to CD in genome-wide scans [30]. An elevation in transcripts encoding several inflammatory cytokines including IL-6, IL-8, IL-17, IL-23 and TNF $\alpha$ is detected in intestinal biopsies from individuals with active CD [31]. On the basis of these results, clinical studies have begun with anti-IL-12p40 (IL-23p40) $[32,33]$ or anti-IL-17 treatment in patients with autoimmune diseases including active CD [7]. Mixed clinical responses are reported in a variety of autoimmune diseases $[7,32,33]$. Our data demonstrate that endogenous IL-10, likely derived from DCs, constrains Th17 cell development through IL-1 in both scenarios. Our results and current clinical trials demonstrate that several key Th17-associated cytokines, rather than one specific cytokine (IL-17 or IL-23), play important roles in human autoimmunity. Thus, to engender reliable and efficient clinical therapeutic efficacy, small molecules, monoclonal antibodies and other recombinant receptor decoys may be designed to simultaneously target multiple crucial inflammatory mediators.

\section{Materials and methods Patients}

Blood was collected from patients with Crohn's disease and healthy volunteers. Fresh colon tissues were collected from patients with Crohn's disease who underwent prophylactic colonic resections or diagnostic biopsies. Fresh "approximately normal" colon tissues adjacent to colorectal carcinoma were also collected as control tissues. All patients with Crohn's disease were in remission and were not treated with steroid drugs or antibiological therapy during the 2 months before the study. Patients involved in the study were consented, and the study was approved by local Institutional Review Boards.

\section{Mice}

6-12-week old female and male C57BL/6 wild-type, IL$10^{-1-}$, and $\mathrm{IL}_{-1} 1 \mathrm{R}^{-1-}$ mice were purchased from the Jackson Laboratory and bred in-house. This research was approved by the committee on Use and Care of Animals at the University of Michigan.

\section{IL-1Ra treatment}

The human recombinant IL-1 receptor antagonist Anakinra was administered at $150 \mathrm{mg} / \mathrm{kg}$ to mice intraperitoneally for 8 days. Mice not receiving Anakinra were injected with PBS vehicle. For treatment of DSS-challenged mice, Anakinra administration $(200 \mathrm{mg} / \mathrm{kg}$ ) began on the first day of the second cycle of DSS and continued through the end of the experiment.

\section{DSS treatment}

Mice were treated with 3\% DSS in water for 5 days, followed by a rest period of 16 days during which they were allowed free access to normal water. This treatment was repeated for a total of two DSS cycles. Mice were sacrificed at the end of the second rest period, and their colons were jelly-rolled, formalin-fixed, and subjected to hematoxylin and eosin (H\&E) staining.

\section{Flow cytometry analysis (FACS)}

Single-cell suspensions were made from human and mouse tissues. Cells were labeled with fluorescence-conjugated antibodies to CD45, CD11c (both Invitrogen), CD90, CD4, CD8, IL-17, FoxP3 (all eBioscience), and/or CD3 (BD Pharmingen). For cytokine profiles, the cells were stimulated, stained and analyzed as previously published[26,34] with FacsDIVA software (BD Biosciences).

\section{Real-time reverse-transcriptase polymerase chain reaction (RT-PCR)}

$\mathrm{Lin}^{-} \mathrm{CD} 11 \mathrm{c}^{+}$cells (DCs) were isolated with a CD11 $\mathrm{c}^{+}$ positive selection kit (StemCell Technologies, Vancouver, British Columbia, Canada) and sorted from IL- $10^{+/+}$ or IL-10 $10^{-1-}$ splenic cells and cultured with or without LPS stimulation. In other experiments, fresh DCs ( $\mathrm{Lin}^{-}$ $\left.\mathrm{CD} 11 \mathrm{c}^{+}\right)$or macrophages $\left(\mathrm{CD} 14^{+}\right)$were isolated and sorted from Crohn's tissue, control colon tissue, or blood. Cytokine transcripts were detected by real-time RT-PCR as previously described [8]. Complementary DNA was normalized against and expressed as the relative values to the house keeping gene gyceraldehyde-3phosphate dehydrogenase (GAPDH). 


\section{T cell culture}

Mouse spleen or human colon DCs and $\mathrm{CD} 4^{+} \mathrm{T}$ cells were co-cultured in a ratio of 1:5 for 5-6 days with anti-CD3 and anti-CD28 antibodies. In other experiments, Crohn's T cells $\left(1 \times 10^{6} / \mathrm{ml}\right)$ were activated for 40 hours with antiCD3 $(5 \mathrm{ug} / \mathrm{ml})$ and anti-CD28 $(2.5 \mathrm{ug} / \mathrm{ml})$. Colon tissue cells $\left(2 \times 10^{6} / \mathrm{ml}\right)$ from colon cancer patients were cultured for 40 hours with medium or $\mathrm{T}$ cell supernatants in the presence of anti-IL-17R antibody ( $R \& D$, clone 133617) or isotype control. Cytokines in cell culture supernatants were detected by ELISA.

\section{ELISA cytokine detection}

Supernatant was collected from culture with mouse T cells and DCs, or LPS-activated DCs, or human colon lamina propria or $\mathrm{CD}^{+}{ }^{+} \mathrm{T}$ cells, or human colon cells and Crohn's $\mathrm{T}$ cells co-culture. In other experiments, fresh serum was collected from the blood of healthy volunteers or Crohn's disease patients. Cytokines were detected using murine or human DuoSet kits (R\&D Systems, Minneapolis, MN).

\section{Statistics}

Experiments were evaluated using the Mann-Whitney or Chi-squared test, with $\mathrm{P}<0.05$ considered significant. Statistics were performed in the GraphPad Prism program suite (GraphPad Software, Inc., La Jolla, CA) and the Statistica program suite (StatSoft, Tulsa, OK).

\section{Results}

Increased IL-17 and Th17 cells in the intestine of patients with Crohn's disease

To investigate if intestinal T cells in patients with Crohn's disease (CD) included Th17 cells, we isolated the lamina propria mononuclear cell fraction from fresh $\mathrm{CD}$ colonic tissues or from "approximately normal" adjacent colonic tissues in patients with colorectal cancer. We detected higher levels of IL-17 in the supernatant of briefly cultured CD lamina propria mononuclear cells than in the supernatant from control lamina propria cells (Figure 1a). This indicates that IL-17 was spontaneously released in the cultures of CD-associated immune cells. After a short stimulation with IL-1 and IL-23, the levels of IL-17 were further increased in cultures of lamina propria mononuclear cells from $\mathrm{CD}$ patients and from control patients. However, the levels of IL-17 were 15 times higher in patients with CD than control (Figure 1a). Interestingly, limited levels of IL-17 were detected in peripheral blood from healthy controls, but were substantially increased in CD patients (Figure 1b). Intracellular staining for IL-17 revealed that IL-17 expression was in $\mathrm{CD}^{+} \mathrm{CD}^{+}$cells. In line with the data on IL-17 in culture supernatants (Figure 1a, b), the numbers of Th17 cells and Foxp $3^{+} \mathrm{CD}_{4}^{+}$regulatory $\mathrm{T}$ cells were significantly higher in the $\mathrm{CD}$ colon tissues than in peripheral blood and the colon tissue from non-CD patients (Figure 1c). The data suggest that Th17 cells may be induced in the local pathological environment in CD patients.

\section{Th17 cells are associated with reduced IL-10 and increased IL-1 in CD patients}

We next examined the potential mechanisms by which Th17 cells were increased in the local CD environment. IL-10 gene polymorphisms that result in defective IL-10 production are observed in patients with CD [21]. We quantified IL-17 and IL-10 transcripts in mononuclear lamina propria cells from patients with $\mathrm{CD}$. The level of IL-10 messages were negatively associated with those of IL-17 (Figure 2a). We hypothesized that decreased IL-10 in $\mathrm{CD}$ patients may allow increased local concentrations of cytokines associated with Th17 cell development. Accordingly, we further quantified TGF $\beta$, IL-1 $\alpha$, IL-1 $\beta$, IL-6, and IL-23 in mononuclear lamina propria cells from patients with CD. The levels of TGF $\beta$, IL-1 $\alpha$, IL-6, and IL-23 were not associated with that of IL-10 (not shown). To our surprise, we observed a significant negative association between IL-1 $\beta$ and IL-10 (Figure $2 b$ ). Not surprisingly, however, was the observation that IL$1 \beta$ and IL-17 message levels correlated directly (Figure 2c). Given the importance of myeloid APC-derived IL-1 in the induction of human Th17 cells[8], we theorized that myeloid APC subsets induced Th17 cells through IL-1 in CD tissues. To test this hypothesis, we demonstrated that both CD macrophages and myeloid dendritic cells (DCs) spontaneously released IL-1 $\beta$, and stimulation with lipopolysaccharide (LPS) further increased the levels of IL-1 $\beta$ (Figure 2d). However, regardless of stimulation, Crohn's intestinal DCs produced higher levels of IL- $1 \beta$ than Crohn's intestinal macrophages and normal intestinal DCs (Figure 2d). This indicates that DCs from CD patients have an increased potential to release IL- $1 \beta$ into the intestinal milieu. Consistent with this, we observed that CD DCs induced higher levels of T cell IL-17 production than macrophages. Blockade of IL-1 receptor signaling reduced $\mathrm{CD}^{+}{ }^{+} \mathrm{T}$ cell-derived $\mathrm{IL}-17$ production induced by both DCs and macrophages (Figure 2e). The data suggest that reduced IL-10 expression by intestinal DCs may promote Th17 cell development through increased IL-1 production in patients with CD.

\section{Th17 cells promote inflammation in CD patients}

Th17 cells may play a role in the pathogenesis of CD [4,35-37]. To directly demonstrate the inflammatory functionality of intestinal Th17 cells, we sorted and activated intestinal $\mathrm{CD}^{+}{ }^{+} \mathrm{T}$ cells from patients with Crohn's disease. Fresh colon tissue cells were exposed to supernatants from activated CD $\mathrm{T}$ cells for a short time. In the absence of CD $\mathrm{T}$ cell supernatant, colon tissue cells 


\section{Blood}

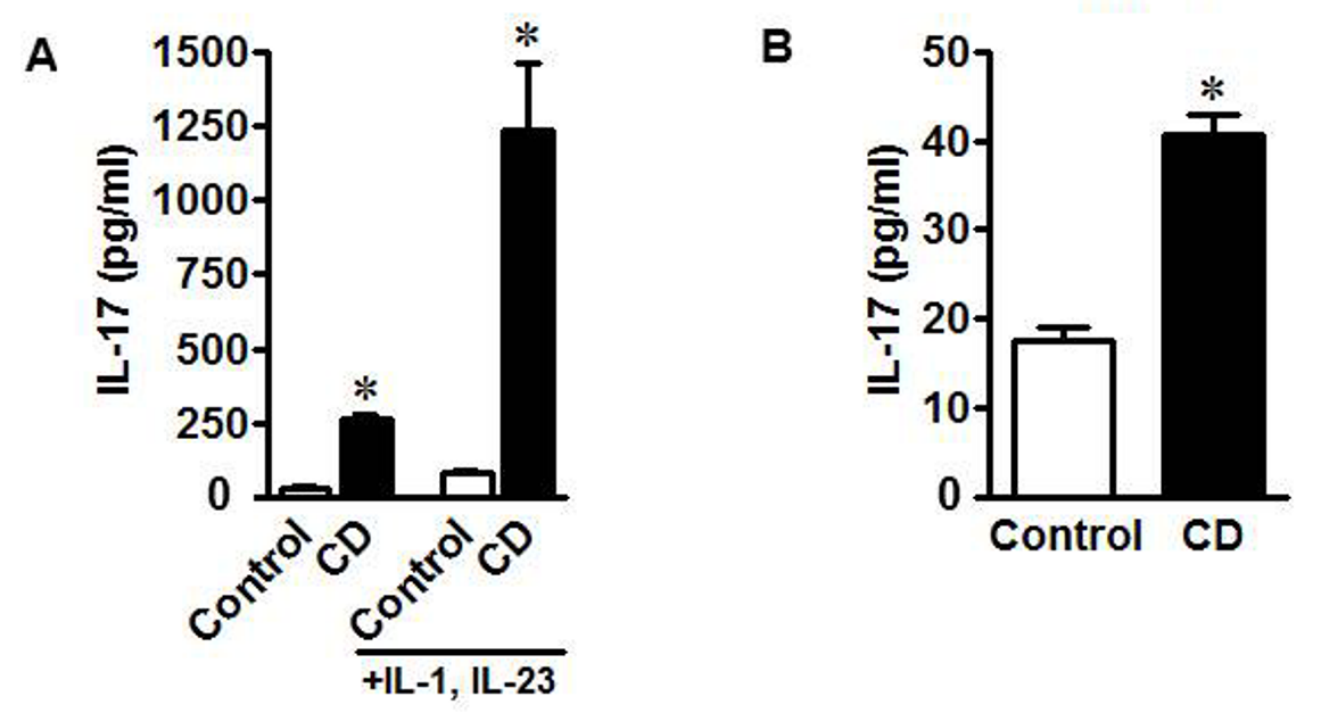

C

Blood
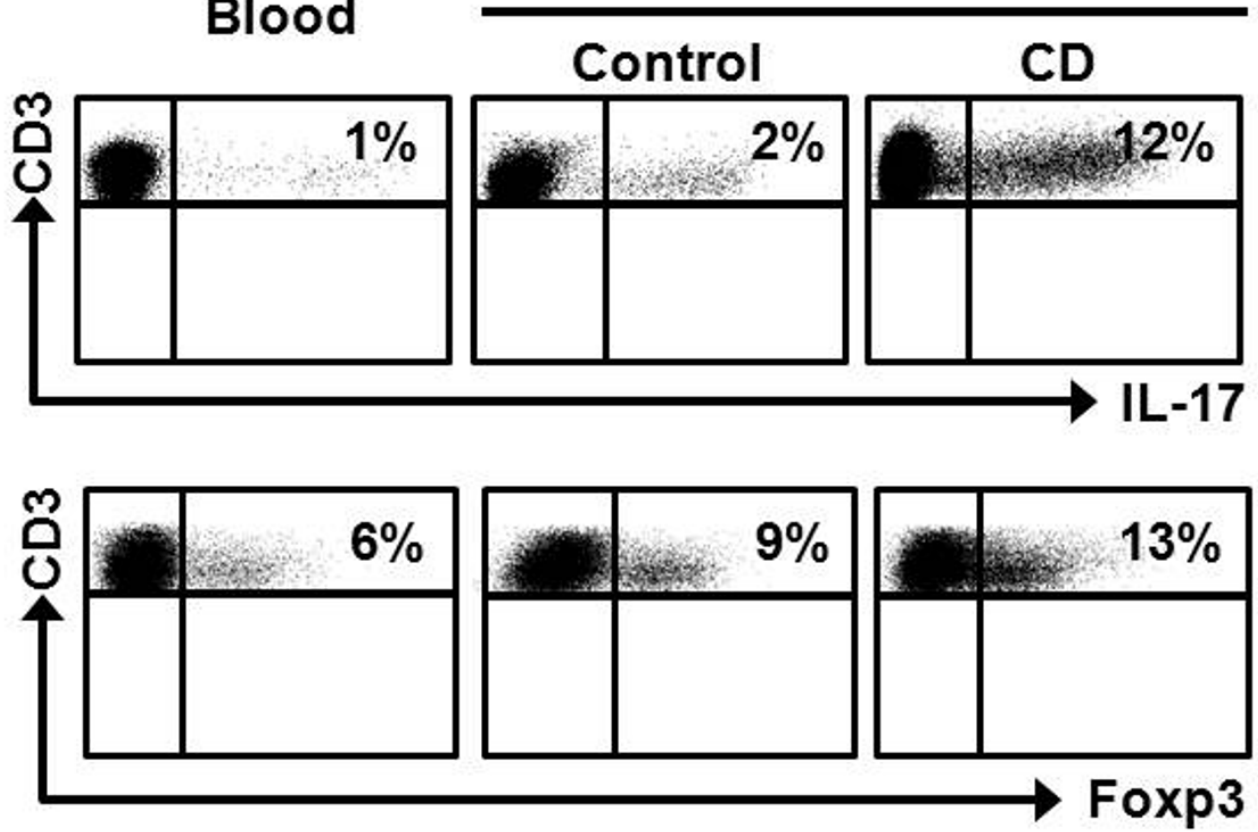

Figure 1 Th17 cells and IL-17 are increased in CD patient tissue. a) Lamina propria mononuclear cells from control colon tissues or CD colons were cultured for two days with IL-1 and IL-23. Supernatants were subjected to ELISA for analysis of IL-17 protein. b) Serum from healthy or CD patients was subjected to ELISA for IL-17 quantification. $n=16$. ${ }^{*} \mathrm{P}<0.0001$. c) Healthy blood or control colon tissue or CD colon tissue cells were stained with antibodies to CD3, CD4, IL-17, and FoxP3 and antigen expression was analyzed via FACS. Results are expressed as the

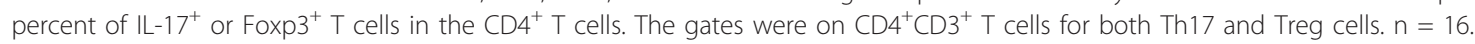


A.

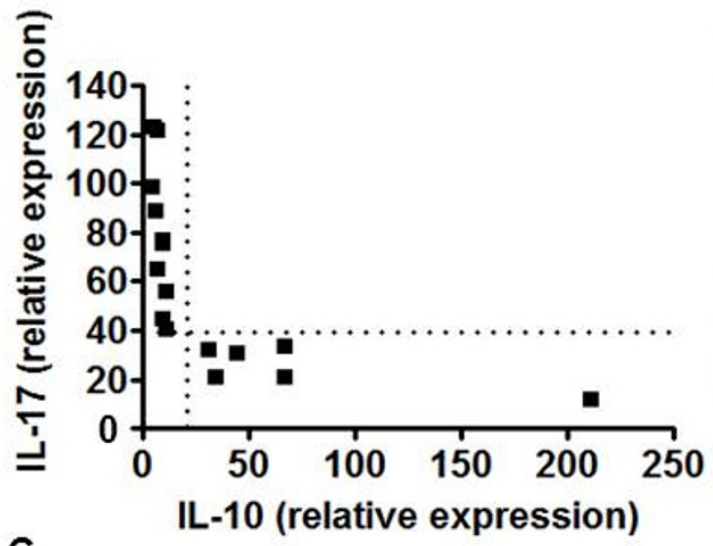

C.

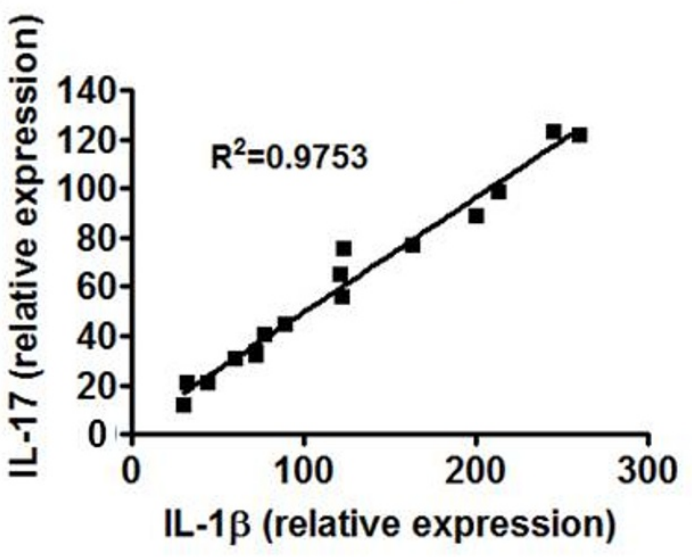

B.

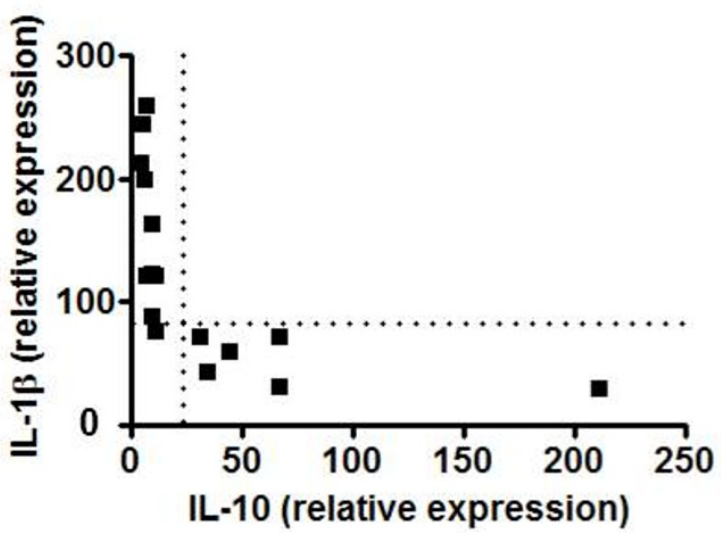

E.

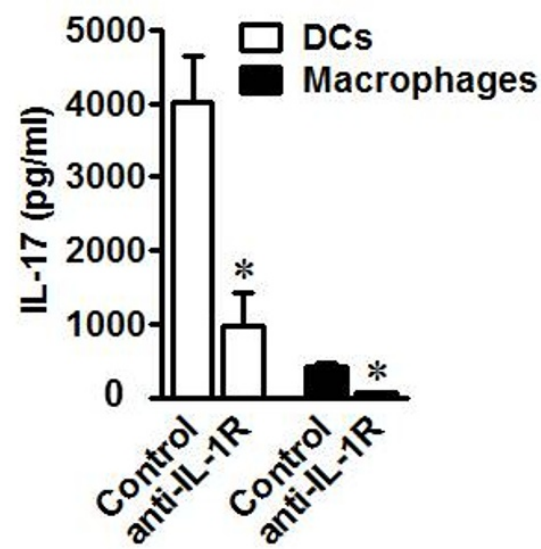

D.

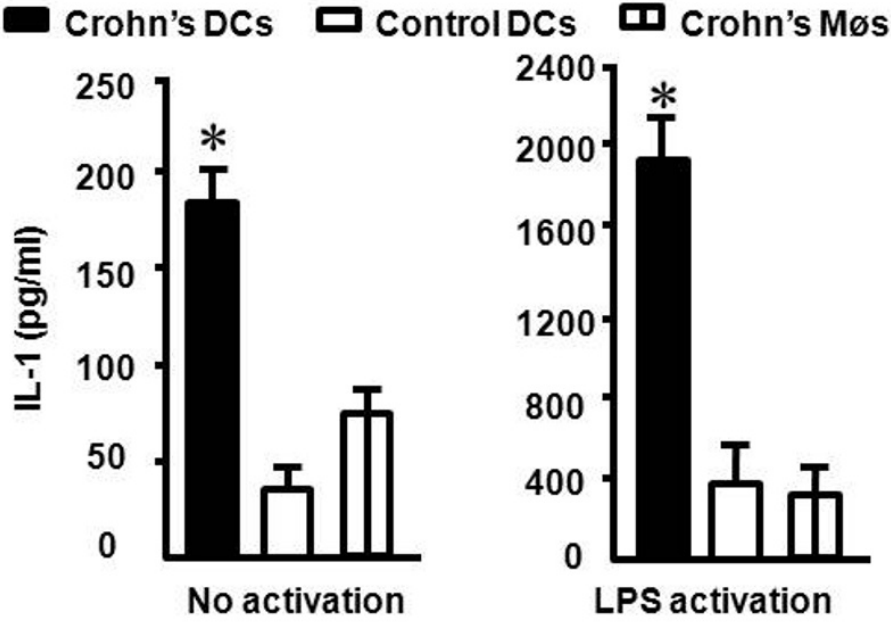

Figure 2 Relationships among IL-17, IL-1, and IL-10 in CD patients. a-C) IL-17, IL-10, and IL-1 $\beta$ message from fresh CD mononuclear lamina propria cells were quantified via real-time PCR. Chi-squared $\left(\chi^{2}\right)$ test. $P<0.0001$ for the following comparisons: IL-17 vs IL-10 (a), IL-1 $1 \beta$ vs IL-10

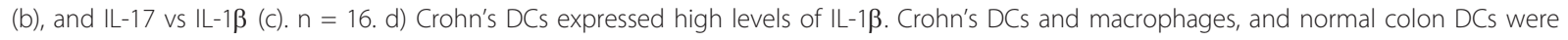
cultured for 40 hours with or without LPS. Normal control DCs were isolated from normal colon tissues at least $5 \mathrm{~cm}$ away from colon cancer. IL-1 $\beta$ protein was quantified via ELISA. $n=6 .{ }^{*}, \mathrm{P}<0.005$. e) Crohn's DCs induced high levels of T cell-derived IL-17 production through IL-1. $\mathrm{CD}^{+} \mathrm{T}$ cells were cultured for 48 hours with Crohn's myeloid DCs or macrophages in the presence anti-IL-1R. IL-17 protein was detected via ELISA in supernatants. $\mathrm{n}=6 .{ }^{*}, \mathrm{P}<0.005$. 
produced minimal amounts of IL-1 $\beta$ (Figure 3a), IL-6 (Figure 3b), and IL-8 (Figure 3c). Interestingly, the levels of IL-1 $\beta$, IL- 6 , and IL-8 protein were dramatically increased in the presence of CD T cell supernatants (Figure $3 \mathrm{a}-\mathrm{c}$ ). Blockade of IL-17 receptor (IL-17R) reduced the production of IL-1 $\beta$, IL- 6 , and IL-8 stimulated by CD $\mathrm{T}$ cell supernatant (Figure $3 \mathrm{a}-\mathrm{c}$ ), suggesting that IL-17 is at least partially responsible for the production of these inflammatory cytokines. Human CD Th17 cells are therefore functional and may play an active pro-inflammatory role in the local disease environment. Thus far, the ex vivo and in vitro data support a cellular and molecular link among IL-10, IL-1 $\beta$, and Th17 cells in humans with CD.

\section{IL-10 ${ }^{-/-}$murine DCs are superior Th17 cell inducers} IL-10 $0^{-1-}$ mice develop chronic enterocolitis, a condition that shares many architectural signatures with human $C D$ [20]. These similarities include increased numbers of focal ulcerations and transmural lesions, as seen in $\mathrm{CD}$ patients [38]. To overcome the experimental limitations of mechanism investigation using limited tissue from $C D$ patients, we extended our studies to the IL-10 $10^{-1-}$ mouse model. We observed increased levels of Th17 cells in the lymph nodes, spleen, blood, and intestines of IL- $10^{-/-}$mice as compared to wild-type $\left(\mathrm{IL}-10^{+/+}\right)$mice (Figure $\left.4 \mathrm{a}, \mathrm{b}\right)$. There were no differences in other immune cell subsets, including B cells, macrophages, DCs, granulocytes, and natural killer cells between IL-10 $0^{-/-}$and $\mathrm{IL}-10^{+/+}$mice (not shown). Thus, Th17 cells are spontaneously and systemically increased in IL-10 $10^{-/-}$mice.

We next studied the potential underlying mechanisms causing the spontaneous increase of Th17 cells in IL$10^{-/-}$mice. To this end, IL- $10^{+/+}$and $\mathrm{IL}-10^{-/-}$spleen T cells were cultured under Th17-polarizing conditions. We observed that there were more Th17 cells in the IL$10^{-/-}$cultures (Figure $4 \mathrm{c}$ ) and more IL-17 in the $\mathrm{IL}-10^{-/-}$ culture supernatant when compared to $\mathrm{IL}-10^{+/+}$cultures (Figure 4d). To examine the cellular cause of the increased Th17 cells, we investigated the role of IL-10 $0^{-1-}$ DCs in Th17 cell induction. We co-cultured wild-type T cells with wild-type DCs or IL-10 $0^{-1-}$ DCs, and examined the resulting cellular phenotypes. We found increased Th17 cells in co-cultures with IL-10 $10^{-1-}$ DCs as compared to those with wild-type DCs (Figure 4e). Thus, similar to human Crohn's DCs, IL-10 ${ }^{-1-}$ mouse DCs are superior inducers of Th17 cells.

\section{IL-10 $0^{-/}$DCs induce Th17 cells through IL-1 in mice}

We next examined possible reasons why murine $\mathrm{IL}-10^{-1-}$ DCs are better at Th17 cell induction. We and others have demonstrated the importance of IL-1 in the development of mouse and human Th17 cells[16,39]. Human Crohn's DCs produced more IL-1, and potently induced Th17 cells (Figure 2d, e). We thus hypothesized that mouse IL-10 $0^{-1-}$ DCs produce more IL-1 which in turn leads to more potent Th17 induction. We first tested this hypothesis in a co-culture system where wild-type
A.

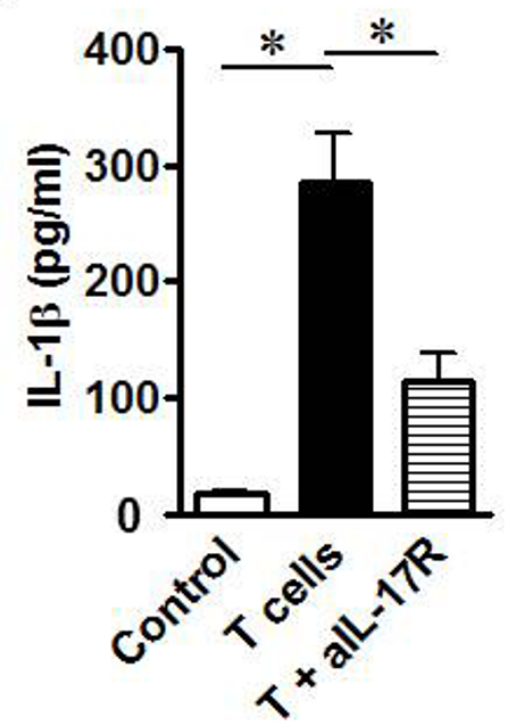

B.

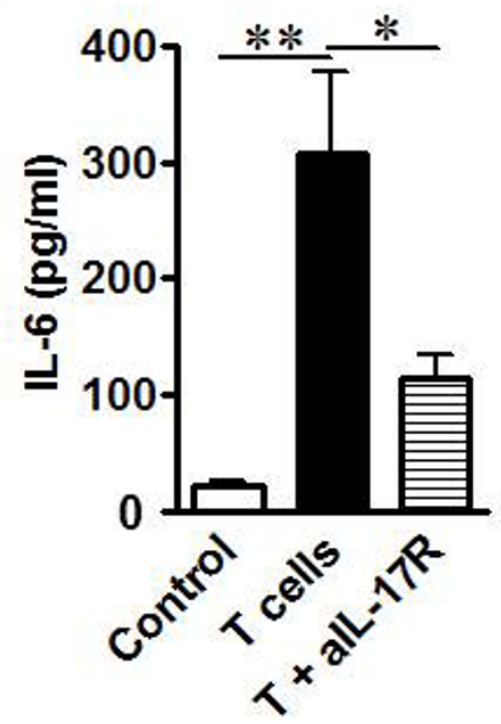

C.

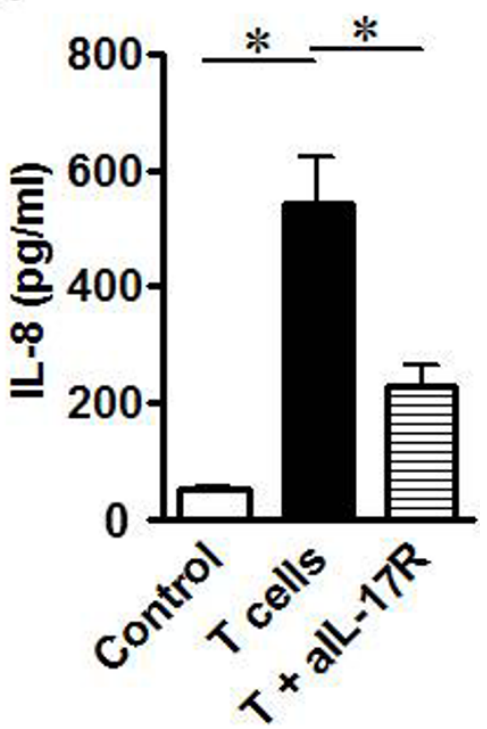

Figure 3 Crohn's disease T cell-derived IL-17 stimulates the production of inflammatory cytokines. "Normal" colon tissue cells were cultured for 40 hours with medium alone or CD T cell supernatants with or without anti-IL-17R. IL-1 3 (a), IL-6 (b), and IL-8 (c) were quantified in supernatant. $\mathrm{n}=5$. $^{*}, \mathrm{P}<0.05$ and ${ }^{* *}, \mathrm{P}<0.01$. 


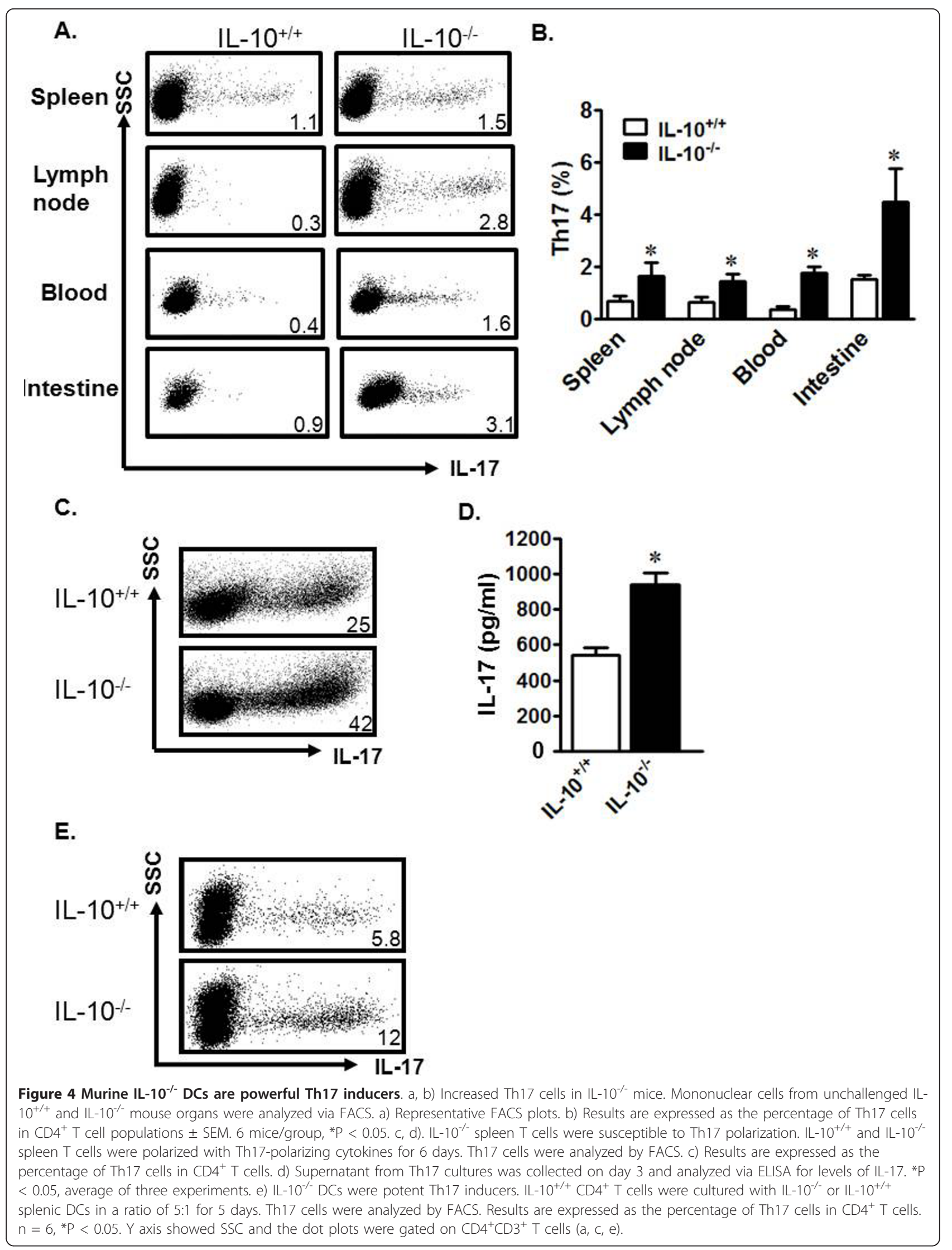


DCs were incubated with either wild-type IL-1 receptor $\left(\mathrm{IL}-1 \mathrm{R}^{+/+}\right.$) or IL-1 $\mathrm{R}^{-/-} \mathrm{T}$ cells. The resultant IL-1 $\mathrm{R}^{-/-} \mathrm{T}$ cell population expressing IL-17 was only half the size of that in the IL-1 $\mathrm{R}^{+/+} \mathrm{T}$ cell cultures (Figure $5 \mathrm{a}$ ). This observation confirms the importance of IL-1 signaling in Th17 development. In line with this finding, we observed increased expression of IL-1 $\alpha$, IL-1 $1 \beta$, IL-6, and TNF $\alpha$ transcripts in IL-10 $0^{-1-}$ DCs when compared to wild-type DCs (Figure 5b and not shown). Increased IL$1 \beta$ protein was also detected in LPS-stimulated IL-10 $10^{-/}$ DC culture supernatants (Figure 5c).

In order to determine whether this increased IL-1 was involved in the stronger Th17 induction documented in our experiments with IL-10 $10^{-1}$ DCs, we added anti-IL-1R to the co-cultures of $\mathrm{T}$ cells with $\mathrm{IL}-10^{+/+}$or $\mathrm{IL}-10^{-/-}$ DCs. Blockade of IL-1R resulted in significantly decreased Th17 cells in both cultures (Figure 5d) and decreased IL-17 levels in culture supernatants (Figure $5 e)$. These data indicate that IL-10 $0^{-1-}$ DCs may release high levels of IL-1 and efficiently promote Th17 cell development.

\section{In vivo blockade of IL-1R signaling decreases Th17 cells and reduces inflammation}

Finally, we investigated whether in vivo blockade of IL-1 signaling had any impact on Th17 cell development. Initially, we administered the human recombinant IL-1R antagonist (IL-1Ra) Anakinra, already shown to have efficacy in mice [40], to IL-10 $1 /++$ and IL-10 $10^{-/-}$mice and analyzed Th17 cells in different organs. As expected, in vivo IL-1 blockade had no significant effect on Th17 cells in wild-type mice (not shown), but decreased Th17 cells in multiple compartments including lymph nodes, spleen, and peripheral blood in IL-10 $10^{-1-}$ mice (Figure 6a). IL-10 $10^{-1-}$ C57BL/6 mice usually do not develop colitis in pathogenfree conditions. To evaluate the link among IL-1, IL-10, and Th17 cells in an active inflammatory environment in vivo, IL-1Ra was administered during the course of dextran sodium sulfate (DSS)-induced colitis in IL-10/- mice. Similarly, we observed that IL-1Ra treatment decreased Th17 cells in multiple organs, including the mesenteric lymph nodes (mLN) (Figure 6b). More interestingly, Anakinra-treated mice did not develop colon polyps, while untreated mice did (Figure 6c). Grossly-evaluated colons from untreated mice exhibited more inflammation and blood vessel involvement than Anakinra-treated mice (Figure 6d). Hematoxylin and eosin (H\&E)-stained sections of mouse colons showed that Anakinra-treated mice had lower inflammatory infiltrate than untreated mice (Figure 6e). These data demonstrate that IL-1 signaling blockade reduces Th17 cells and ameliorates chemically-induced inflammation. Our work therefore demonstrates a potent cellular and molecular link between IL-10 and Th17 cells in mice and in humans with Crohn's disease.

\section{Discussion}

In the present study, we established a cellular and molecular relationship among IL-1, IL-10, and Th17 cell development in inflammatory disease models in humans and mice. This link may be important in the regulation of immune pathogenesis of human chronic inflammatory conditions, including CD.

Th17 cells play a role in the inflammatory response associated with multiple human autoimmune diseases [4,41-43] and cancer [8,9]. Th17 cells and/or IL-17 are detected in CD patients [35-37,44-48]. However, the generation and functional relevance of Th17 cells remains poorly understood in $\mathrm{CD}$ patients. We have tested the functionality of fresh CD Th17 cells, and found that these $\mathrm{T}$ cells induce the production of IL-1, IL- 6 , and IL- 8 by colon tissue cells through IL-17 in vitro. It suggests that these cells may mediate or/and accelerate local inflammation by inducing inflammatory cytokine production. In line with this, elevated inflammatory cytokines are detected in the freshly isolated colon environment from patients with $\mathrm{CD}$. It has been reported that recombinant IL-17 induces IL-6 expression in other systems [49-52]. As IL-1, IL-6, and IL-8 play crucial roles in CD [53-57], it is likely that Th17 cells promote the production of inflammatory cytokines and contribute to the immunopathogenesis of CD in patients. Notably, although IL-17, as a signature gene for Th17 cells, importantly attributes to Th17 cell biology, it is well appreciated that Th17 cell biology may depend on the synergistic effects between Th17associated cytokines, rather than IL-17 alone $[8,58]$. For example, IL-17 and IFN $\gamma$ synergistically induce $\beta$-defensin expression in patients with psoriasis [6] and Th1-type chemokine production in patients with cancer [8]. This may partially explain why IL-17 signaling blockade generates variable clinical benefits in patients with psoriasis, rheumatoid arthritis, and uveitis [7] and minimal clinical response in patients with $\mathrm{CD}$.

We have demonstrated a cellular and molecular link among IL-10, IL-1, and Th17 cells in patients with CD and in IL-10 $10^{-1-}$ mice. In CD patients, the levels of intestinal IL-10 are negatively associated with IL-17 and IL-1. Both IL-10 $0^{-1-}$ mouse DCs and human Crohn's DCs are superior inducers of Th17 cells via their increased IL-1 production. Blockade of the IL-1 signaling pathway reduces Th17 cell development both in vitro and in vivo. In agreement with these observations, we and others have shown that IL-1 is crucial for inducing Th17 cells in humans and mice $[16,59]$. In patients with psoriasis, psoriatic DCs potently induce Th17 cells in an IL-1dependent manner [6]. Human tumor-associated macrophages also promote Th17 cell development through IL1 [8]. IL-1 has been shown to induce gastric inflammation and is associated gastric carcinoma [1]. Notably, IL10 suppresses IL-1 production $[60,61]$ and that IL-1 is 
A.

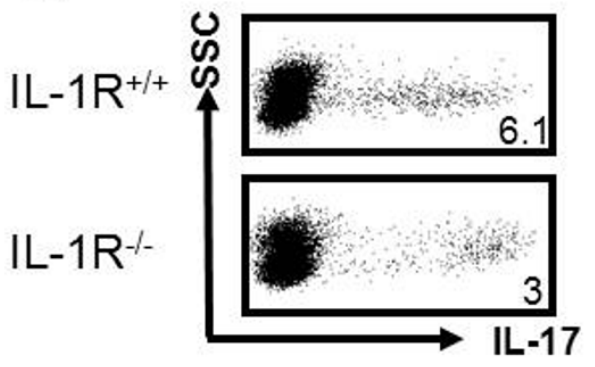

C.

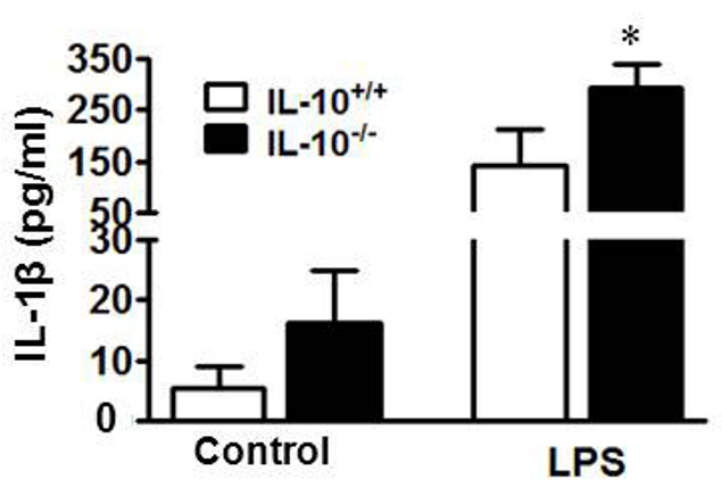

B.
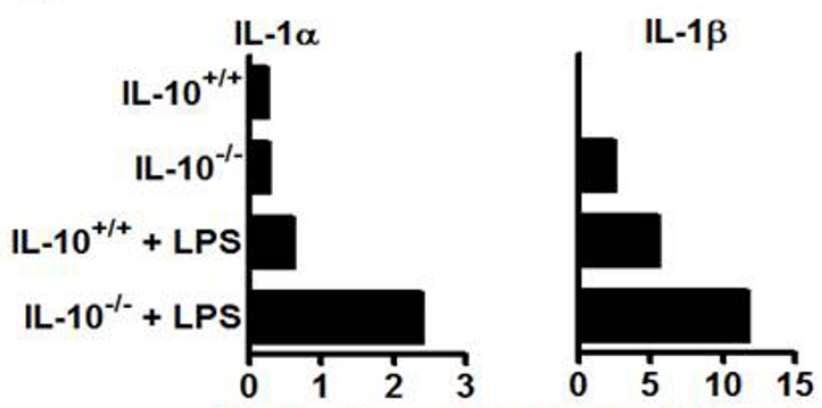

Relative Expression Relative Expression

D.

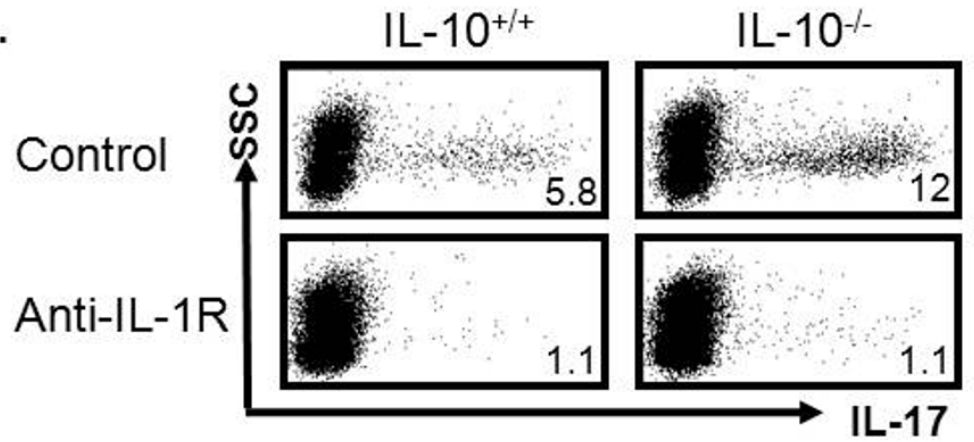

E.

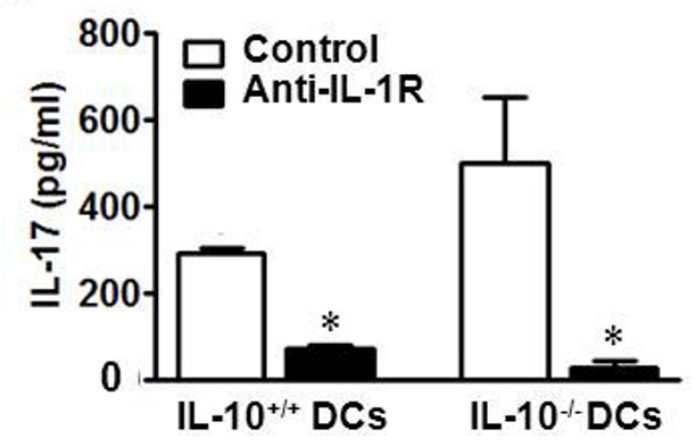

Figure 5 Mouse IL-10 ${ }^{-/}$DCs induce Th17 cells through the IL-1/IL-1R signaling pathway. a) Reduced Th17 cells in DC-stimulated IL-1R

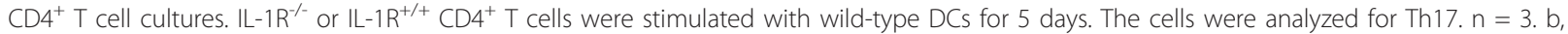

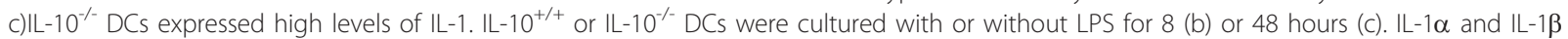
message was quantified via real-time PCR (b). IL-1 $1 \beta$ protein was detected in culture supernatant via ELISA (c). *P $<0.05$, average of 3 experiments. $d$, e) Blockade of IL-1R reduced DC-mediated Th17 induction. IL-10 $0^{-/-}$or IL-10 $0^{+/+}$DCs were cultured in a ratio of 1:5 with IL-10/++ $\mathrm{CD}^{+} \mathrm{T}$ cells with or without anti-IL-1R. The cells were analyzed on day 5 for Th17. Results are expressed as the percentage of Th17 cells in CD4 T cells (d). IL-17 was detected in culture supernatants on day 3 via ELISA. Results are expressed as the mean values \pm SEM (e). $n=4$. ${ }^{*}, P<0.05$. $Y$ axis showed SSC and the dot plots were gated on $\mathrm{CD}^{+} \mathrm{CD}^{+} \mathrm{T}$ cells $(\mathrm{a}, \mathrm{d})$. 


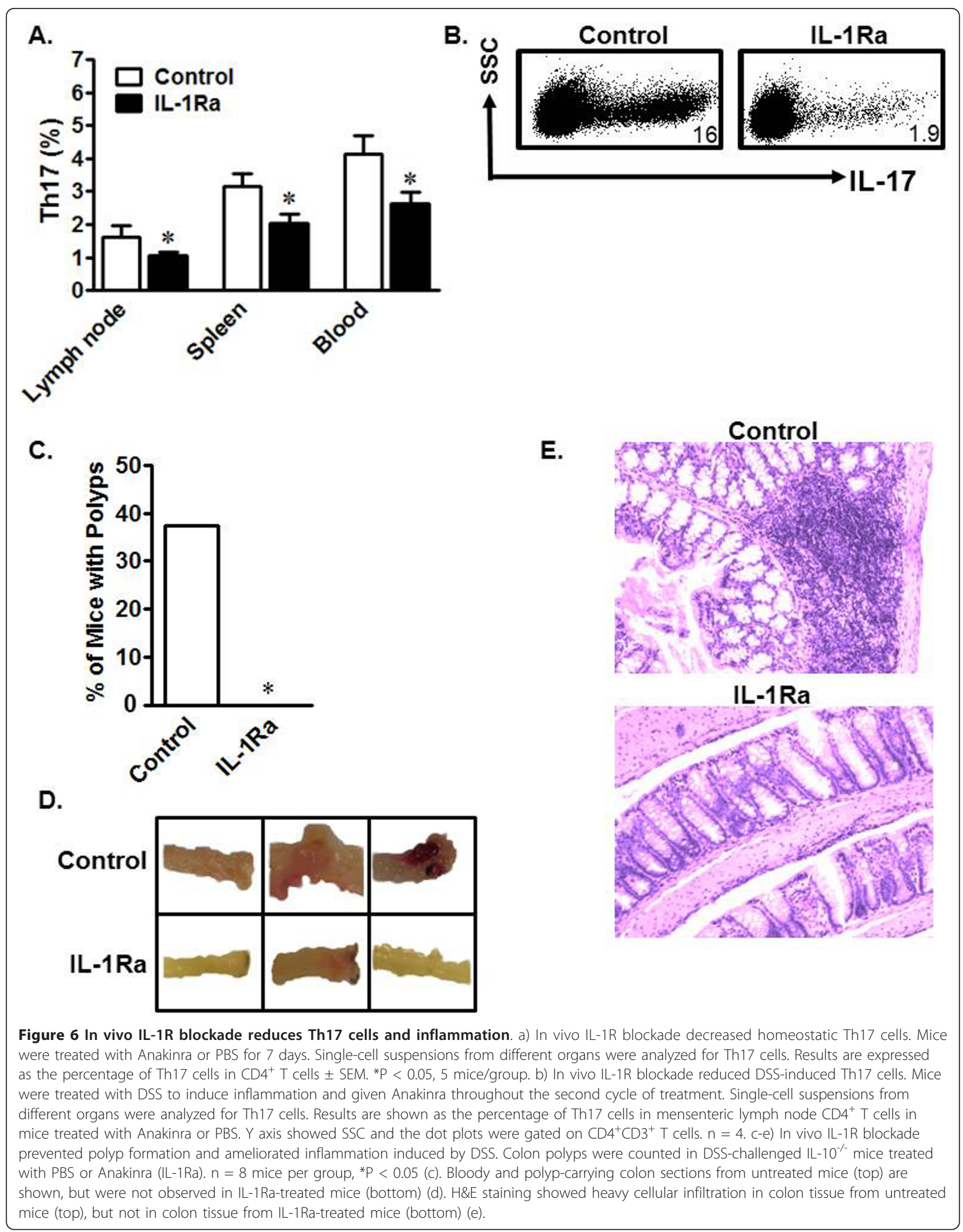


involved in controlling Th17 cells in the mouse model of experimental autoimmune encephalomyelitis (EAE) [39]. Exogenous IL-10 can suppress the in vitro development of Th17 cells from $\mathrm{CD}^{+} \mathrm{T}$ cells in patients with rheumatoid arthritis [62]. However, our study is the first to demonstrate a role for IL-10 in Th17 development through the control of IL-1 expression by DCs in both mouse and human systems, including CD patients. In support of our studies in patients with $\mathrm{CD}$, one recent report demonstrates that mouse Th17 cells expressed interleukin-10 receptor $\alpha$ (IL-10R $\alpha)$ in vivo. Importantly, $\mathrm{T}$ cell specific blockade of IL-10 signaling led to a selective increase of Th17 cells during intestinal inflammation in the small intestine in mice. Furthermore, in this mouse model, Treg cells were able to control Th17 cells in an IL-10-dependent manner in vivo. Thus IL-10 signaling directly suppresses Th17 cells [63]. However, high levels of Treg cell infiltration are detected in patients with CD and ulcerative colitis [64]. Although Treg cells inhibit Th17 cells in patients with cancer [8], it appears that human Treg cells failed doing so in the microenvironments of chronic graft-versus-host disease (GVHD), ulcerative colitis, and inflammation-associated colon cancer $[9,64]$. It is possible that human Th17 cells have stem cell features and are resistant to apoptosis in the chronic inflammatory microenvironments $[9,64]$. Nonetheless, our data indicate that IL-1 plays a key role in Th17 cell development in human autoimmune disease, and support the notion that IL-1 signaling blockade is a potential strategy to treat patients with these conditions. IL-10, via its downregulation of IL-1, is thus able to limit development of Th17 cells in mice and humans, and in doing so executes some of its anti-inflammatory effects.

The next logical step is to investigate how IL-10 controls IL-1 production by APCs. IL-10 dampens MyD88dependent signaling in DCs and leads to LPS hyporesponsiveness [65]. Because IL-1 signaling can be mediated by MyD88, this may explain how IL-10 controls endotoxin-induced IL-1 production. It is also possible that IL-10 controls IL-1 expression machinery, such as IL-1 converting enzyme (ICE) and components of the inflammasome $[66,67]$. However, it remains to be determined if IL-10 suppresses IL-1 production induced by other stimuli, including the necrotic tissue often found in a chronic inflammatory environment. The key question remaining is why IL-10 production is reduced in some $\mathrm{CD}$ patients. A nucleotide-binding oligomerization domain containing 2 (NOD2) mutation commonly observed in CD patients may lead to inhibition of IL-10 transcription [21]. However, we have not examined the gene profile of NOD expression in our patient populations. Since $30 \%$ of CD patients have NOD mutations, it is likely that alterations in NOD2 transcription may at least partially contribute to the reduced IL-10 production in our patient tissues. The data further suggests that IL10 therapy or IL-1 signaling blockade may not be generally meaningful for all the $\mathrm{CD}$ patients.

In summary, we have demonstrated that IL-10 targets APCs, and suppresses Th17 cell development in mice and humans through modulation of IL-1 production. The data document a cellular and molecular link among IL-10, IL1 , and Th17 cells, and suggest that IL-10 may inhibit inflammation via control of Th17 cell development.

\section{Conclusions}

To date, it is well accepted that Th17 cells play a role in inflammation including Crohn's disease. Our studies have demonstrated that IL-1 drives the immune effector status towards IL-17, and dendritic cell-derived IL-10 constraints Th17 cell development through IL-1 in patients with $\mathrm{CD}$. This is the first report demonstrating cellular and molecular mechanistic link among IL-1, IL10 and Th17 cells in patients with CD. This link is functionally examined in mouse model. Demonstration of the novel mechanistic interplay between inflammatory and anti-inflammatory elements increases our understanding of $C D$ pathogenesis and can identify novel pathways involved in disease aetiology.

\section{Abbreviations \\ Th: T-helper; Treg: regulatory T; IL: interleukin; APC: antigen-presenting cell; DC: dendritic cell; Crohn's disease: CD.}

\section{Acknowledgements}

We thank Deborah Postiff and Monica Muzzin in the tissue procurement core for their technical assistance. This research is supported (in part) by $\mathrm{NIH/NCl} \mathrm{R01} \mathrm{grants} \mathrm{(CA099985,} \mathrm{CA0156685,} \mathrm{CA152470)} \mathrm{and} \mathrm{the} \mathrm{NIH} \mathrm{through}$ the University of Michigan's Cancer Center Support Grant (5 P30 CA46592).

\section{Author details}

'Department of Surgery, University of Michigan, Ann Arbor, MI, USA. ${ }^{2}$ Graduate Program in Immunology, University of Michigan, Ann Arbor, MI, USA. ${ }^{3}$ Department of Medicine, University of Michigan, Ann Arbor, MI, USA. ${ }^{4}$ Department of Medicine, Renji Hospital, Shanghai Jiao-Tong University, Shanghai, P. R. China. ${ }^{5}$ University of Michigan Comprehensive Cancer Center, Ann Arbor, MI, USA. ${ }^{6}$ Graduate Program in Cancer Biology, Ann Arbor, MI, USA.

\section{Authors' contributions}

CMW, LW, IK and SW performed experiments. EH, JK and WZ obtained funding, provided material and intellectual support. CMW and WZ wrote the paper. All authors read and approved the final manuscript. CMW, LW and SW contributed equally to this work.

\section{Competing interests}

The authors declare that they have no competing interests.

Received: 11 August 2011 Accepted: 16 December 2011 Published: 16 December 2011

\section{References}

1. Tu S, Bhagat G, Cui G, Takaishi S, Kurt-Jones EA, Rickman B, Betz KS, PenzOesterreicher M, Bjorkdahl O, Fox JG, Wang TC: Overexpression of interleukin-1 beta induces gastric inflammation and cancer and mobilizes myeloid-derived suppressor cells in mice. Cancer Cell 2008, 14:408-419.

2. Coussens LM, Werb Z: Inflammation and cancer. Nature 2002, 420:860-867. 
3. Du C, Liu C, Kang J, Zhao G, Ye Z, Huang S, Li Z, Wu Z, Pei G: MicroRNA miR-326 regulates $\mathrm{TH}-17$ differentiation and is associated with the pathogenesis of multiple sclerosis. Nat Immunol 2009, 10:1252-1259.

4. Kleinschek MA, Boniface K, Sadekova S, Grein J, Murphy EE, Turner SP, Raskin L, Desai B, Faubion WA, de Waal Malefyt R, et al: Circulating and gut-resident human Th17 cells express CD161 and promote intestinal inflammation. J Exp Med 2009, 206:525-534.

5. Kryczek I WK, Zhao E, Wei S, Vatan L, Szeliga W, Huang E, Greenson J, Chang A, Roliński J, Radwan P, Fang J, Wang G, Zou W: IL-17+ Regulatory T Cells in the Microenvironments of Chronic Inflammation and Cancer. Journal of Immunology 2011.

6. Kryczek I, Bruce AT, Gudjonsson JE, Johnston A, Aphale A, Vatan L, Szeliga W, Wang Y, Liu Y, Welling TH, et al: Induction of IL-17+ T cell trafficking and development by IFN-gamma: mechanism and pathological relevance in psoriasis. J Immunol 2008, 181:4733-4741.

7. Hueber W, Patel DD, Dryja T, Wright AM, Koroleva I, Bruin G, Antoni C, Draelos Z, Gold MH, Durez P, et al: Effects of AIN457, a fully human antibody to interleukin-17A, on psoriasis, rheumatoid arthritis, and uveitis. Sci Transl Med 2010, 2:52ra72.

8. Kryczek I, Banerjee M, Cheng P, Vatan L, Szeliga W, Wei S, Huang E, Finlayson $\mathrm{E}$, Simeone D, Welling TH, et al: Phenotype, distribution, generation, and functional and clinical relevance of Th17 cells in the human tumor environments. Blood 2009, 114:1141-1149.

9. Kryczek I, Zhao E, Liu Y, Wang Y, Vatan L, Szeliga W, Moyer J, Klimczak A, Lange A, Zou W: Human TH17 Cells Are Long-Lived Effector Memory Cells. Sci Transl Med 2011, 3:104ra100.

10. Veldhoen M, Hocking RJ, Atkins CJ, Locksley RM, Stockinger B: TGFbeta in the context of an inflammatory cytokine milieu supports de novo differentiation of IL-17-producing T cells. Immunity 2006, 24:179-189.

11. Bettelli E, Carrier Y, Gao W, Korn T, Strom TB, Oukka M, Weiner HL, Kuchroo VK: Reciprocal developmental pathways for the generation of pathogenic effector TH17 and regulatory T cells. Nature 2006, 441:235-238.

12. Mangan PR, Harrington LE, O'Quinn DB, Helms WS, Bullard DC, Elson CO, Hatton RD, Wahl SM, Schoeb TR, Weaver CT: Transforming growth factorbeta induces development of the $\mathrm{T}(\mathrm{H}) 17$ lineage. Nature 2006, 441:231-234.

13. Nakae $S$, Iwakura $Y$, Suto $H$, Galli SJ: Phenotypic differences between Th1 and Th17 cells and negative regulation of Th1 cell differentiation by IL17. J Leukoc Biol 2007, 81:1258-1268.

14. McGeachy MJ, Chen Y, Tato CM, Laurence A, Joyce-Shaikh B, Blumenschein WM, McClanahan TK, O'Shea JJ, Cua DJ: The interleukin 23 receptor is essential for the terminal differentiation of interleukin 17producing effector T helper cells in vivo. Nat Immunol 2009, 10:314-324.

15. Laurence A, Tato CM, Davidson TS, Kanno Y, Chen Z, Yao Z, Blank RB, Meylan F, Siegel R, Hennighausen $L$, et al: Interleukin-2 signaling via STAT5 constrains T helper 17 cell generation. Immunity 2007, 26:371-381.

16. Kryczek I, Wei S, Vatan L, Escara-Wilke J, Szeliga W, Keller ET, Zou W: Cutting Edge: Opposite Effects of IL-1 and IL-2 on the Regulation of IL-17+ T Cell Pool IL-1 Subverts IL-2-Mediated Suppression. J Immunol 2007, 179:1423-1426.

17. Dong C: TH17 cells in development: an updated view of their molecular identity and genetic programming. Nat Rev Immunol 2008, 8:337-348.

18. Kolls JK, Linden A: Interleukin-17 family members and inflammation. Immunity 2004, 21:467-476.

19. Ouyang $W$, Kolls JK, Zheng $Y$ : The biological functions of $T$ helper 17 cell effector cytokines in inflammation. Immunity 2008, 28:454-467.

20. Kuhn R, Lohler J, Rennick D, Rajewsky K, Muller W: Interleukin-10-deficient mice develop chronic enterocolitis. Cell 1993, 75:263-274.

21. Noguchi E, Homma Y, Kang X, Netea MG, Ma X: A Crohn's diseaseassociated NOD2 mutation suppresses transcription of human IL10 by inhibiting activity of the nuclear ribonucleoprotein hnRNP-A1. Nat Immunol 2009, 10:471-479.

22. Vicari AP, Trinchieri G: Interleukin-10 in viral diseases and cancer: exiting the labyrinth? Immunol Rev 2004, 202:223-236.

23. O'Garra A, Murphy KM: From IL-10 to IL-12: how pathogens and their products stimulate APCs to induce $\mathrm{T}(\mathrm{H}) 1$ development. Nat Immunol 2009, 10:929-932.

24. Enk AH, Katz SI: Identification and induction of keratinocyte-derived IL10. J Immunol 1992, 149:92-95.
25. Jung HC, Eckmann L, Yang SK, Panja A, Fierer J, Morzycka-Wroblewska E, Kagnoff MF: A distinct array of proinflammatory cytokines is expressed in human colon epithelial cells in response to bacterial invasion. J Clin Invest 1995, 95:55-65.

26. Kryczek I, Zou L, Rodriguez P, Zhu G, Wei S, Mottram P, Brumlik M, Cheng P, Curiel T, Myers L, et al: B7-H4 expression identifies a novel suppressive macrophage population in human ovarian carcinoma. J Exp Med 2006, 203:871-881.

27. Curiel TJ, Wei S, Dong H, Alvarez X, Cheng P, Mottram P, Krzysiek R, Knutson KL, Daniel B, Zimmermann MC, et al: Blockade of B7-H1 improves myeloid dendritic cell-mediated antitumor immunity. Nat Med 2003, 9:562-567

28. Zou W, Chen L: Inhibitory B7-family molecules in the tumour microenvironment. Nat Rev Immunol 2008, 8:467-477.

29. Moore KW, de Waal Malefyt R, Coffman RL, O'Garra A: Interleukin-10 and the interleukin-10 receptor. Annu Rev Immunol 2001, 19:683-765.

30. Duerr RH, Taylor KD, Brant SR, Rioux JD, Silverberg MS, Daly MJ, Steinhart AH, Abraham C, Regueiro M, Griffiths A, et al: A genome-wide association study identifies IL23R as an inflammatory bowel disease gene. Science 2006, 314:1461-1463.

31. Holtta V, Klemetti P, Sipponen T, Westerholm-Ormio M, Kociubinski G, Salo H, Rasanen L, Kolho KL, Farkkila M, Savilahti E, Vaarala O: IL-23/IL-17 immunity as a hallmark of Crohn's disease. Inflamm Bowel Dis 2008, 14:1175-1184.

32. Mannon PJ, Fuss IJ, Mayer L, Elson CO, Sandborn WJ, Present D, Dolin B, Goodman N, Groden C, Hornung RL, et al: Anti-interleukin-12 antibody for active Crohn's disease. N Engl J Med 2004, 351:2069-2079.

33. Sandborn WJ, Feagan BG, Fedorak RN, Scherl E, Fleisher MR, Katz S, Johanns J, Blank M, Rutgeerts P: A randomized trial of Ustekinumab, a human interleukin-12/23 monoclonal antibody, in patients with moderate-to-severe Crohn's disease. Gastroenterology 2008, 135:1130-1141.

34. Curiel TJ, Coukos G, Zou L, Alvarez X, Cheng P, Mottram P, EvdemonHogan M, Conejo-Garcia JR, Zhang L, Burow M, et al: Specific recruitment of regulatory $T$ cells in ovarian carcinoma fosters immune privilege and predicts reduced survival. Nat Med 2004, 10:942-949.

35. Annunziato F, Cosmi L, Santarlasci V, Maggi L, Liotta F, Mazzinghi B, Parente E, Fili L, Ferri S, Frosali F, et al: Phenotypic and functional features of human Th17 cells. J Exp Med 2007, 204:1849-1861.

36. Rovedatti L, Kudo T, Biancheri P, Sarra M, Knowles CH, Rampton DS, Corazza GR, Monteleone G, Di Sabatino A, Macdonald TT: Differential regulation of interleukin 17 and interferon gamma production in inflammatory bowel disease. Gut 2009, 58:1629-1636.

37. Bogaert S, Laukens D, Peeters $H$, Melis L, Olievier K, Boon N, Verbruggen G, Vandesompele J, Elewaut D, De Vos M: Differential mucosal expression of Th17-related genes between the inflamed colon and ileum of patients with inflammatory bowel disease. BMC Immunol 2010, 11:61.

38. Berg DJ, Davidson N, Kuhn R, Muller W, Menon S, Holland G, ThompsonSnipes L, Leach MW, Rennick D: Enterocolitis and colon cancer in interleukin-10-deficient mice are associated with aberrant cytokine production and CD4(+) TH1-like responses. J Clin Invest 1996, 98:1010-1020.

39. Sutton C, Brereton C, Keogh B, Mills KH, Lavelle EC: A crucial role for interleukin (IL)-1 in the induction of IL-17-producing $\mathrm{T}$ cells that mediate autoimmune encephalomyelitis. J Exp Med 2006, 203:1685-1691.

40. Surguladze D, Deevi D, Claros N, Corcoran E, Wang S, Plym MJ, Wu Y, Doody J, Mauro DJ, Witte $L$, et al: Tumor necrosis factor-alpha and interleukin-1 antagonists alleviate inflammatory skin changes associated with epidermal growth factor receptor antibody therapy in mice. Cancer Res 2009, 69:5643-5647.

41. Kebir H, Kreymborg K, Ifergan I, Dodelet-Devillers A, Cayrol R, Bernard M, Giuliani F, Arbour N, Becher B, Prat A: Human TH17 lymphocytes promote blood-brain barrier disruption and central nervous system inflammation. Nat Med 2007, 13:1173-1175.

42. Melton AC, Bailey-Bucktrout SL, Travis MA, Fife BT, Bluestone JA, Sheppard D: Expression of alphavbeta8 integrin on dendritic cells regulates Th17 cell development and experimental autoimmune encephalomyelitis in mice. J Clin Invest 2010, 120:4436-4444.

43. Annunziato F, Cosmi L, Liotta F, Maggi E, Romagnani S: Type $17 \mathrm{~T}$ helper cells-origins, features and possible roles in rheumatic disease. Nat Rev Rheumatol 2009, 5:325-331. 
44. Nielsen $\mathrm{OH}$, Kirman I, Rudiger N, Hendel J, Vainer B: Upregulation of interleukin-12 and -17 in active inflammatory bowel disease. Scand J Gastroenterol 2003, 38:180-185.

45. Saruta M, Yu QT, Avanesyan A, Fleshner PR, Targan SR, Papadakis KA: Phenotype and effector function of CC chemokine receptor 9-expressing lymphocytes in small intestinal Crohn's disease. J Immunol 2007, 178:3293-3300.

46. Beltran CJ, Candia E, Erranz B, Figueroa C, Gonzalez MJ, Quera R, Hermoso MA: Peripheral cytokine profile in Chilean patients with Crohn's disease and ulcerative colitis. Eur Cytokine Netw 2009, 20:33-38.

47. Seiderer J, Elben I, Diegelmann J, Glas J, Stallhofer J, Tillack C, Pfennig S, Jurgens M, Schmechel S, Konrad A, et al: Role of the novel Th17 cytokine IL-17F in inflammatory bowel disease (IBD): upregulated colonic IL-17F expression in active Crohn's disease and analysis of the IL17F p. His161Arg polymorphism in IBD. Inflamm Bowel Dis 2008, 14:437-445.

48. Hovhannisyan Z, Treatman J, Littman DR, Mayer L: Characterization of IL17-producing regulatory $T$ cells in inflamed intestinal mucosa from patients with inflammatory bowel diseases. Gastroenterology 2010

49. Laan M, Cui ZH, Hoshino H, Lotvall J, Sjostrand M, Gruenert DC, Skoogh BE, Linden A: Neutrophil recruitment by human IL-17 via C-X-C chemokine release in the airways. J Immunol 1999, 162:2347-2352.

50. Hata K, Andoh A, Shimada M, Fujino S, Bamba S, Araki Y, Okuno T, Fujiyama Y, Bamba T: IL-17 stimulates inflammatory responses via NFkappaB and MAP kinase pathways in human colonic myofibroblasts. Am J Physiol Gastrointest Liver Physiol 2002, 282:G1035-1044.

51. Shimada M, Andoh A, Hata K, Tasaki K, Araki Y, Fujiyama Y, Bamba T: IL-6 secretion by human pancreatic periacinar myofibroblasts in response to inflammatory mediators. J Immunol 2002, 168:861-868.

52. Andoh A, Takaya H, Makino J, Sato H, Bamba S, Araki Y, Hata K, Shimada M, Okuno T, Fujiyama Y, Bamba T: Cooperation of interleukin-17 and interferon-gamma on chemokine secretion in human fetal intestinal epithelial cells. Clin Exp Immunol 2001, 125:56-63.

53. Pallone F, Monteleone G: Mechanisms of tissue damage in inflammatory bowel disease. Curr Opin Gastroenterol 2001, 17:307-312.

54. McCormack G, Moriarty D, O'Donoghue DP, McCormick PA, Sheahan K, Baird AW: Tissue cytokine and chemokine expression in inflammatory bowel disease. Inflamm Res 2001, 50:491-495.

55. Murata $Y$, Ishiguro $Y$, Itoh J, Munakata A, Yoshida $Y$ : The role of proinflammatory and immunoregulatory cytokines in the pathogenesis of ulcerative colitis. J Gastroenterol 1995, 30(Suppl 8):56-60.

56. Baumgart DC, Carding SR: Inflammatory bowel disease: cause and immunobiology. Lancet 2007, 369:1627-1640.

57. Baumgart DC, Sandborn WJ: Inflammatory bowel disease: clinical aspects and established and evolving therapies. Lancet 2007, 369:1641-1657.

58. Zou W, Restifo NP: $\mathrm{T}(\mathrm{H}) 17$ cells in tumour immunity and immunotherapy. Nat Rev Immunol 2010, 10:248-256.

59. Chung $Y$, Chang SH, Martinez GJ, Yang XO, Nurieva R, Kang HS, Ma L Watowich SS, Jetten AM, Tian Q, Dong C: Critical regulation of early Th17 cell differentiation by interleukin-1 signaling. Immunity 2009, 30:576-587.

60. Kawachi S, Jennings S, Panes J, Cockrell A, Laroux FS, Gray L, Perry M, van der Heyde H, Balish E, Granger DN, et al: Cytokine and endothelial cell adhesion molecule expression in interleukin-10-deficient mice. Am J Physiol Gastrointest Liver Physiol 2000, 278:G734-743.

61. Toth LA, Opp MR: Cytokine- and microbially induced sleep responses of interleukin-10 deficient mice. Am J Physiol Regul Integr Comp Physiol 2001, 280:R1806-1814

62. Heo YJ, Joo YB, Oh HJ, Park MK, Heo YM, Cho ML, Kwok SK, Ju JH, Park KS, Cho SG, et al: IL-10 suppresses Th17 cells and promotes regulatory T cells in the CD4+ T cell population of rheumatoid arthritis patients. Immunol Lett 2010, 127:150-156.

63. Huber S, Gagliani N, Esplugues E, O'Connor W Jr, Huber FJ, Chaudhry A, Kamanaka M, Kobayashi Y, Booth CJ, Rudensky AY, et al: Th17 cells express interleukin-10 receptor and are controlled by Foxp3 and Foxp3+ regulatory $\mathrm{CD} 4+\mathrm{T}$ cells in an interleukin-10-dependent manner. Immunity 2011, 34:554-565.

64. Kryczek I, Wu K, Zhao E, Wei S, Vatan L, Szeliga W, Huang E, Greenson J, Chang A, Rolinski J, et al: IL-17(+) regulatory T cells in the microenvironments of chronic inflammation and cancer. J Immunol 2011 186:4388-4395.
65. Chang J, Kunkel SL, Chang CH: Negative regulation of MyD88-dependent signaling by IL-10 in dendritic cells. Proc Natl Acad Sci USA 2009, 106:18327-18332.

66. Fantuzzi $\mathrm{G}$, Dinarello CA: Interleukin-18 and interleukin-1 beta: two cytokine substrates for ICE (caspase-1). J Clin Immunol 1999, 19:1-11.

67. Martinon F, Burns K, Tschopp J: The inflammasome: a molecular platform triggering activation of inflammatory caspases and processing of prolLbeta. Mol Cell 2002, 10:417-426.

doi:10.1186/1479-5876-9-217

Cite this article as: Wilke et al.: Endogenous interleukin-10 constrains Th17 cells in patients with inflammatory bowel disease. Journal of Translational Medicine 2011 9:217.

\section{Submit your next manuscript to BioMed Central and take full advantage of:}

- Convenient online submission

- Thorough peer review

- No space constraints or color figure charges

- Immediate publication on acceptance

- Inclusion in PubMed, CAS, Scopus and Google Scholar

- Research which is freely available for redistribution

Submit your manuscript at www.biomedcentral.com/submit
Biomed Central 